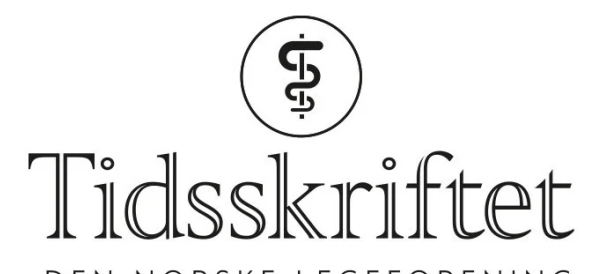

DEN NORSKE LEGEFORENING

\title{
To underlige lederartikler
}

BREV TIL REDAKTØREN

\section{ODDBJØRN BRUBAKK}

Oddbjørn Brubakk (f. 1940) er dr.med. og spesialist i indremedisin og i infeksjonssykdommer. Han er pensjonist og arbeider deltid ved ME/CFS-senteret, Oslo universitetssykehus, Aker.

Forfatter har fylt ut ICMJE-skjemaet og oppgir ingen interessekonflikter.

Oslo 


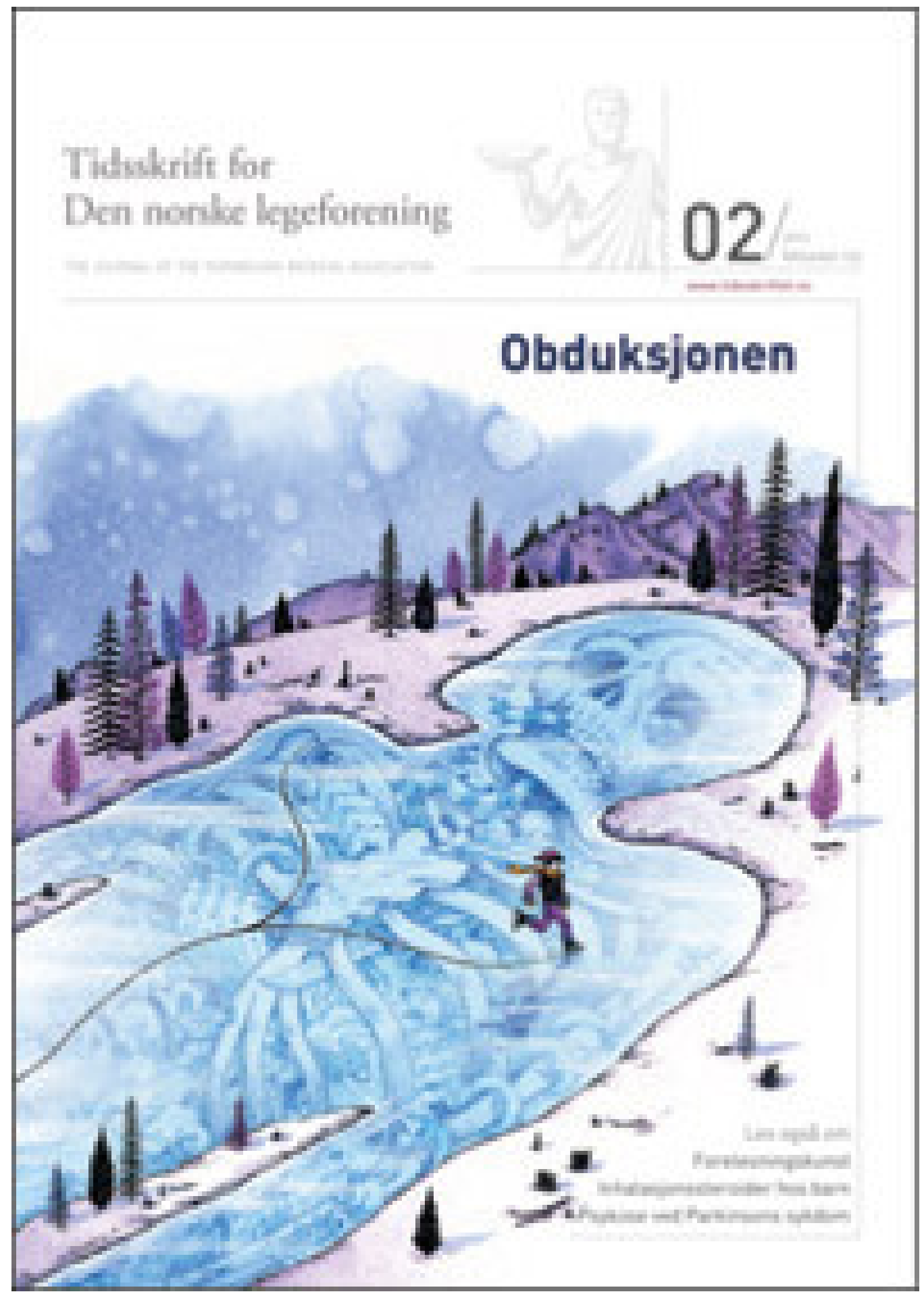

I Tidsskriftet nr. 2/2012 og nr. 3/2012 er det to underlige ledere av henholdsvis Stine

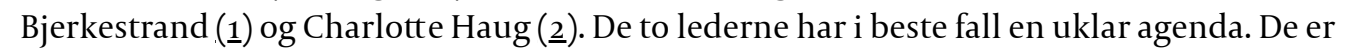
skrevet på en måte som jeg oppfatter som diskreditering av forskere som har gjort en mønstergyldig studie som gir håp for tusenvis av pasienter. Denne blir satt opp mot en metaanalyse av Lillebeth Larun \& Kirsti Malterud, som ble publisert i Tidsskriftet i 2011 (3). Sistnevnte er der faglig medarbeider. Bjerkestrands leder er allerede kommentert av flere. Hun er bekymret for at Larun \& Malteruds studie ble møtt med taushet og overser et leserbrev (4.) der det blir hevdet at trening ved utmattelsessyndrom kan være farlig.

Stine Bjerkestrand (1) forstår ikke hvorfor Larun \& Malteruds artikkel ikke fikk samme oppmerksomhet i mediene som Fluge og medarbeideres studie (5). Hun beskriver den som en liten klinisk studie der det antydes at sykdommen er autoimmun og hevder at det er tonet ned at studien er i en tidlig fase og at vi vet lite om langtidsvirkninger og 
bivirkninger. Hun harselerer over at en forfatter har fulgt forskerne tett og at bloggere har omtalt studien samtidig som den ble publisert. Verst av alt er at Fluge og medarbeidere har fått 2 millioner kroner til videre forskning.

I en ny leder beroliger Charlotte Haug (2) med at Tidsskriftet ikke har tatt parti i «MEstriden». Lederen starter med en fiasko, nemlig at viruset XMRV ble antatt å være årsak til utmattelsessyndrom, men viste seg å være et sannsynlig laboratorieskapt artefakt - i tillegg til at det er påvist uredelighet og juks i artikkelen. Hva har dette med denne saken å gjøre? Er det for å antyde at forskerne bak rituximabstudien kan ha tatt feil, eventuelt jukset? Hun mener det trengs mer og bredere forskning, fortrinnsvis utført av en uavhengig gruppe. Uavhengig av hva? Av Haukeland universitetssykehus, som har finansiert studien?

Det er vanskelig å forstå annet enn at Tidsskriftet har tatt standpunkt i «ME-striden» - og det i klart favør for det som presenteres i metaanalysen. For oss andre bringer metaanlaysen ingen ny kunnskap - den er unyansert, lite kritisk og lite relevant i klinisk arbeid. Rituximabstudien, derimot. er gjennomført på en mønstergyldig måte og kan antyde noe om patogenesen ved kronisk utmattelsessyndrom. Det gir håp for de mange som lider av sykdommen.

De to lederartiklene tjener etter min mening Tidsskriftet til liten ære.

\section{LITTERATUR}

1. Bjerkestrand S. Maktskiftet. Tidsskr Nor Legeforen 2012; 132: 125. [PubMed]

2. Haug C. Meningsvokterne. Tidsskr Nor Legeforen 2012; 132: 261. [PubMed]

3. Larun L, Malterud K. Treningsbehandling ved kronisk utmattelsessyndrom. Tidsskr Nor Legeforen 2011; 131: 231-6. [PubMed]

4. Twisk FN, Maes M, Festvåg L. Gradert treningsterapi kan ha skadelige effekter. Tidsskr Nor Legeforen 2011; 131: 803. [PubMed]

5. Fluge $\emptyset$, Bruland O, Risa K et al. Benefit from B-lymphocyte depletion using the anti-CD2o antibody rituximab in chronic fatigue syndrome. A double-blind and placebo-controlled study. PLoS ONE 2011; 6: e26358. [PubMed] [CrossRef]

Publisert:30. april 2012. Tidsskr Nor Legeforen. DOI:10.4045/tidsskr.12.0202

(C) Tidsskrift for Den norske legeforening 2023. Lastet ned fra tidsskriftet.no 26. april 2023. 